\title{
Simulation of Weld Elbows Hot Forming Process
}

\author{
J. Zajac, P. Beraxa, P. Michalík, F. Botko, and M. Pollák
}

\begin{abstract}
Presented article is focused on mathematical simulation of forming process of weld elbows for the purpose of production process improvement. Necessity of simulation and subsequent experimental verification of results is based on problems during the manufacturing process of weld elbows. Simulations were made using Deform 3D and final shapes of arcs were subsequently analyzed. Simulation in software is realized using finite elements method. The simulations were held under ideal conditions and with ideal shape of spike end tool. Models of semi products were based on requirements from the industry. Subsequently will be performed experimental verification of obtained data by manufacturing of test samples using unimproved tool. Goal of analyses is to achieve shape of the spike end tool with no further necessity of adjustment for obtaining correct final product.
\end{abstract}

Index Terms-Forming process, material, simulation, spike end tool, weld pipe elbow.

\section{INTRODUCTION}

Mathematical simulations are currently very effective way to predict shape and properties of final products, which simplify and cheapen construction and preparation of production process. Presented article is aimed on mathematical simulation of production weld pipe arc $76,1 \times$ $2,9 \mathrm{~mm}$. Necessity of simulation and subsequent experimental verification of results is based on problems during the manufacturing process of weld elbows. Spike end tool is special designed tool to form elbows, but in manufacturing process are often requirements on changes of tools shape from the reason of additional correction of the product shape. Described process must be repeated always after tool lifetime, where individual processes represent time demands what affect downtimes of productions, what directly influence economical profits. Following significant factor is disruption of the surface layer of the spike end tool made of lost wax casting technology as a result of grinding process after tool modification in production what result in reduction tools lifetime.

\section{PREPARATION OF Simulation}

Simulation was realized by using software Deform 3D. Aim of simulation was to obtain ideal dimensions of weld pipe elbow manufactured with ideal condition settings. Results obtained from simulation will be used as "bouncing

Manuscript received January 21, 2016; revised March 23, 2016.

J. Zajac, P. Michalík, F. Botko, and M. Pollák are with Technical University of Kosice, Faculty of Manufacturing Technologies with A Seat in Presov, Bayerova 1, 08001 Presov, Slovakia (e-mail: jozef.zajac@tuke.sk, peter.michalik@tuke.sk, frantisek.botko@tuke.sk, martin.pollak@tuke.sk).

P. Beraxa is with ŽP Research and Development Centre, Kolkáreň 35, 97681 Podbrezová, Slovakia (e-mail: pavol.beraxa@tuke.sk). ramp" for subsequent analyses and experimental verification, which are intended to achieve and prescribe shape and dimensions of spike end tool, which do not need additional manual operations. Weld pipe elbows are made of steel according to EN S 235 JRH (STN 11 353). Material S235 is non-alloy quality structural steel intended for manufacturing of seamless pipes. Steel grade is generally suitable to welding. Chemical composition and mechanical properties are shown in tables below (Table I-III). Properties of material EN S 235 JRH were used in simulation process to acquire precise results [1]-[3].

TABLE I: CHEMICAL COMPOSITION OF STEEL S 235 JRH

\begin{tabular}{|c|c|c|c|c|}
\hline \multicolumn{5}{|c|}{ Chemical composition [\%] } \\
\hline $\mathrm{C}$ & $\mathrm{Mn}$ & $\mathrm{P}$ & $\mathrm{S}$ & $\mathrm{N}$ \\
\hline $\max \quad 0.2$ & $\max 1.4$ & $\max \quad 0.04$ & $\max \quad 0.04$ & $\max \quad 0.009$ \\
\hline
\end{tabular}

TABLE II: MECHANICAL PROPERTIES OF S 235 JRH

\begin{tabular}{|c|c|c|c|}
\hline \multicolumn{4}{|c|}{ Mechanical properties } \\
\hline Rm (MPa) & $\operatorname{Re}(\mathrm{MPa})$ & $\mathrm{KV}(\mathrm{J})$ & $\mathrm{A}(\%)$ \\
\hline $360-510$ & $\min .235$ & 27 & $\min .26$ \\
\hline
\end{tabular}

TABLE III: ELASTIC PROPERTIES OF STEEL S 235 JRH

\begin{tabular}{|c|c|c|}
\hline & $\begin{array}{c}\text { Young's module of elasticity } \\
{[\mathrm{MPa}]}\end{array}$ & Poisson's ratio \\
\hline S 235 JRH & 210000 & 0,3 \\
\hline
\end{tabular}

Spike end tool (Fig. 1) is made of steel according to ISO STN 17322 (Cr-Ni-W-Mo steel). Depend on fact, that in simulation was tool considers as an ideal rigid solid and for simplifying the process of simulation was ignored heat transfer, although the chemical and mechanical properties do not significantly affect the simulation processes [4], [5].

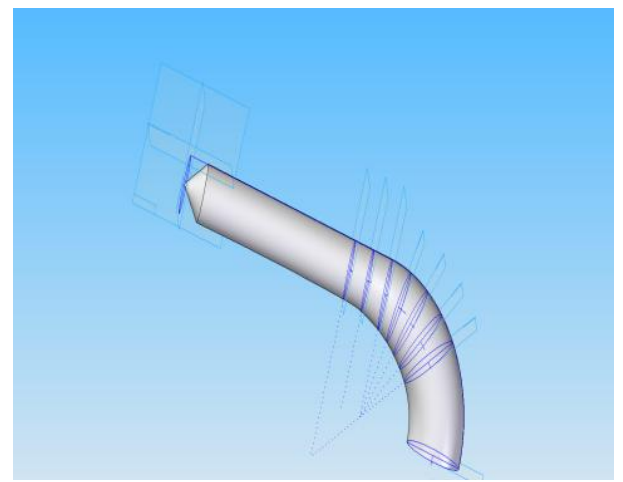

Fig. 1. 3D model of tool. 


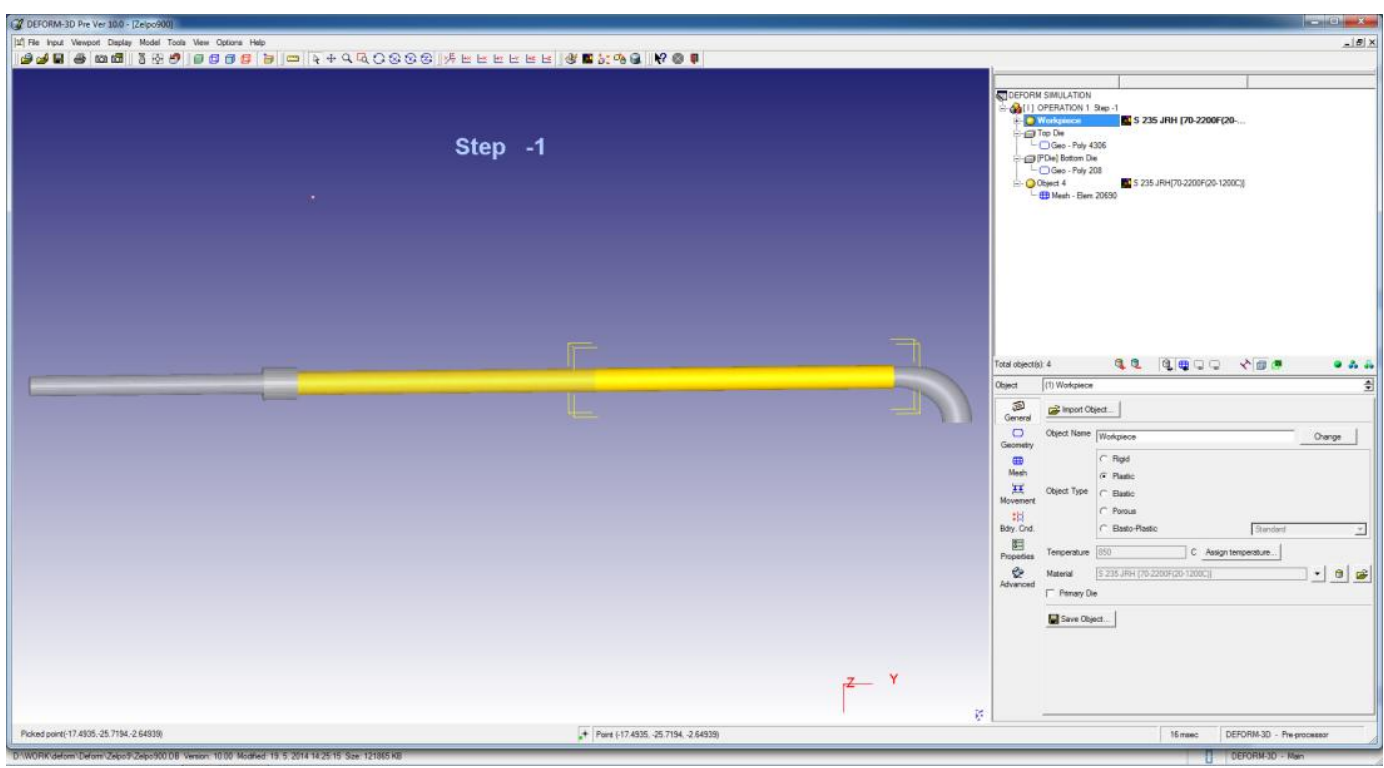

Fig. 2. Imported models of semi product and tool in environment of software Deform 3D.

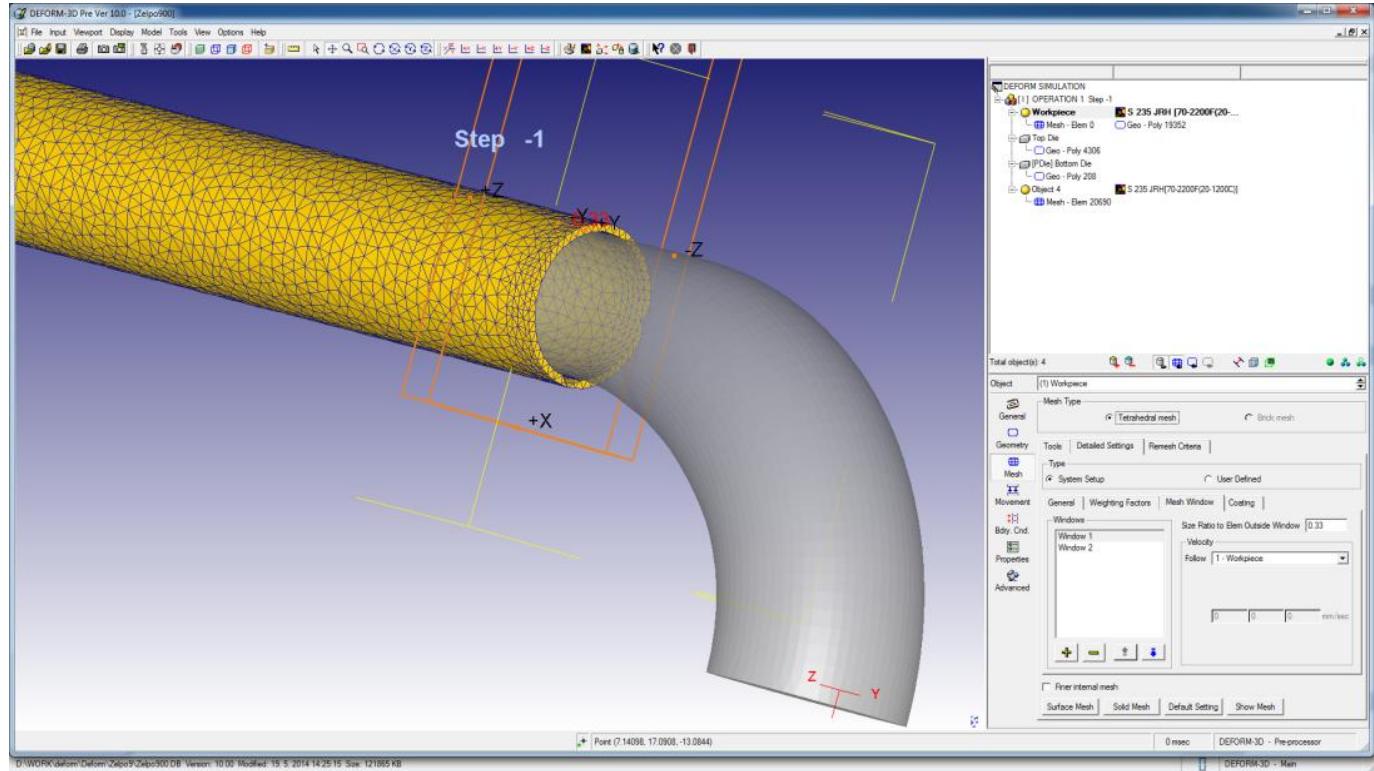

Fig. 3. Compressed mesh of FEM (Mesh Window).

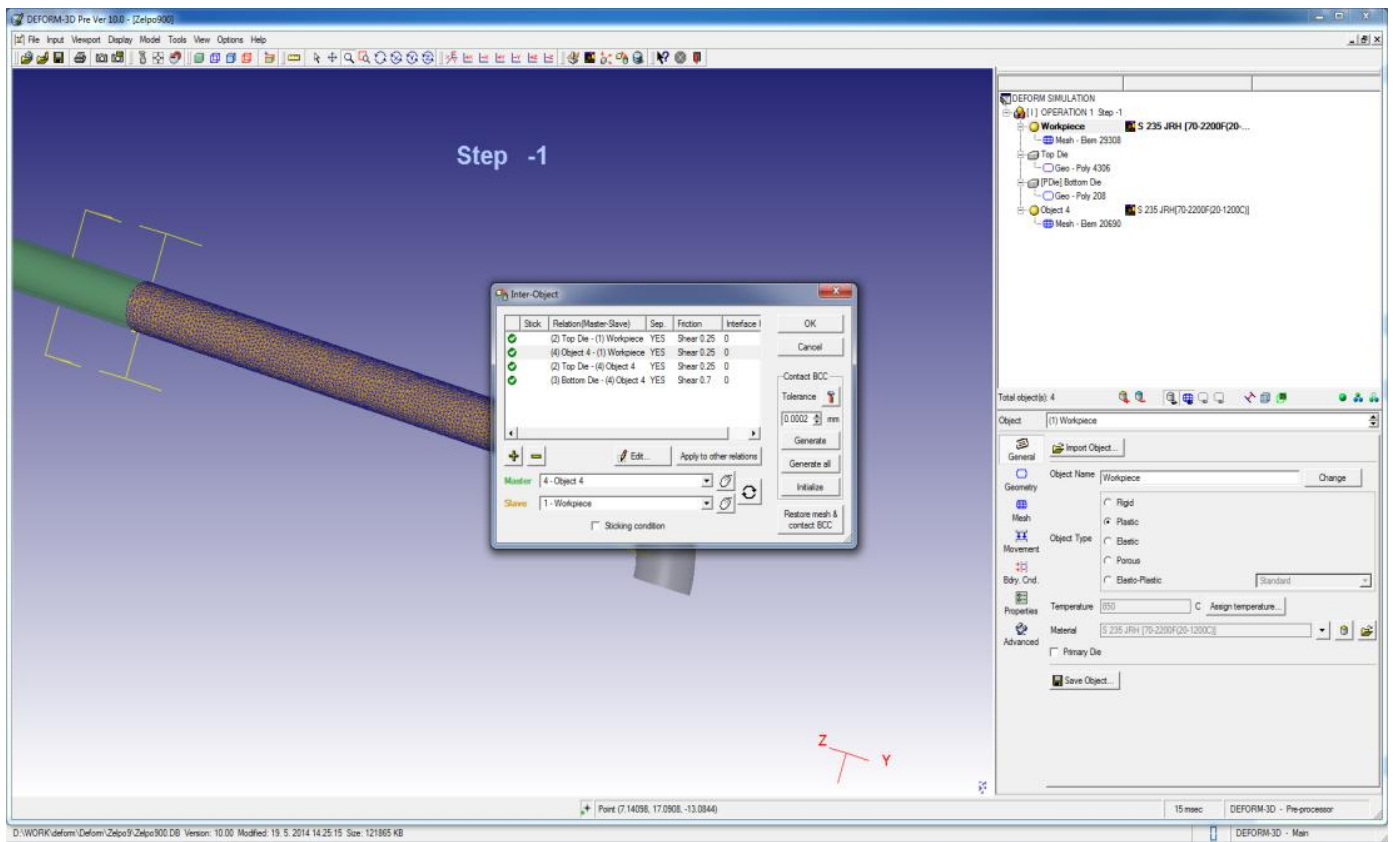

Fig. 4. Define of friction parameters 


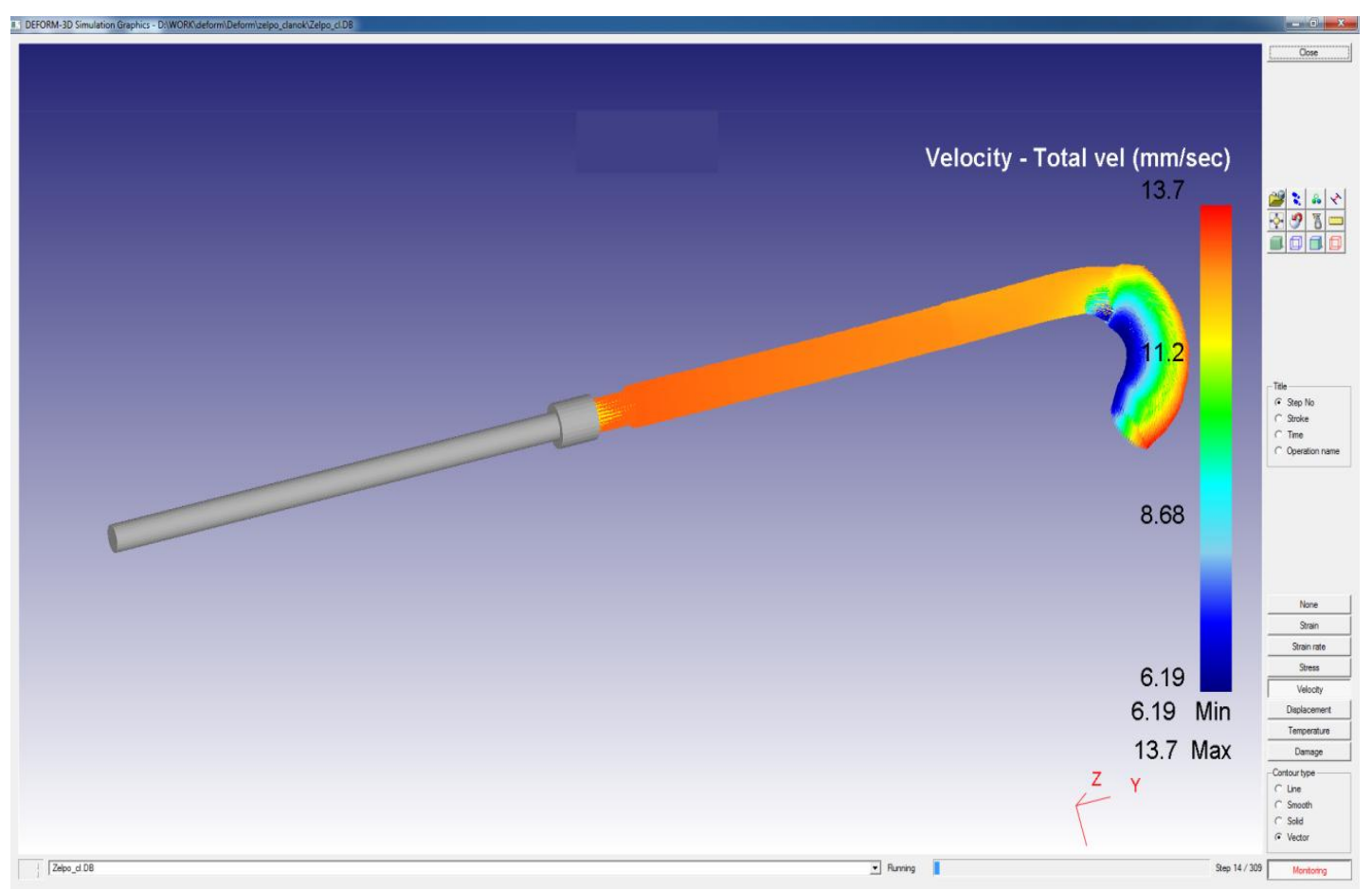

Fig. 5. Simulation process.

Models of semi products were based on requirements from the industry and were realized in environment of the software Deform 3D (Fig. 2).

\section{CONDitions OF THE Simulation}

Simulation in software Deform 3D is realized using finite elements method. Deform provide possibility to set number elements, where for simulation part was set 200000 finite elements for tool. For ends of pipes was created compressed mesh of finite element in ratio 1:0,33 (Mesh Window) (Fig. 3) to improve contact conditions. This preset allows creating smaller finite elements on regions of the workpieces which are in contact for elimination of distortion in simulation process.

Simulation could be adversely affected by biggest compression ratio. Workpiece was defined as plastic material. Deformation preset was set as "Active in FEM + meshing". [6]-[8] Boundary conditions define contact between workpieces to provide permanent contact during simulation process (preset COMFORM COUPLING in Deform 3D). Symmetry planes were not set by the reality from the reason of subsequent research should point on eccentricity of pipes (dimension and shape). Temperature for hot forming is in documentation prescribes on $850^{\circ} \mathrm{C}$.

Simulation process was considered with using constant temperature without possibility of heat transfer, what reduce time of simulation. Temperature of spike end tool was set on $780^{\circ} \mathrm{C}$, velocity of pushed plate was set according to manufacture requirement. Interaction between objects were set by values selected from library in Deform 3D for warm forming on values 0,25 (Fig. 4) for friction between workpieces and tool, which is for simulation purposes represent one unit with guide rod using method of comfort coupling. [7]-[9].

\section{Simulation}

Simulation was realized overall in 1000 steps with step 1 $\mathrm{mm}$. Process of simulation can be observed in real time with monitoring actual values of velocity, temperature, deformation, strain etc (Fig. 5) [10].

Finish simulation provide to obtain data and values, which can be evaluate using post processor. In the fact of aim to geometry parameters of final product the model was extracted in STereoLithography format (*.stl), what provide possibility to reverse convert model into solid model in CAD software and subsequently measure and verify required/prescribed dimensions and geometrical parameters (Fig. 6).
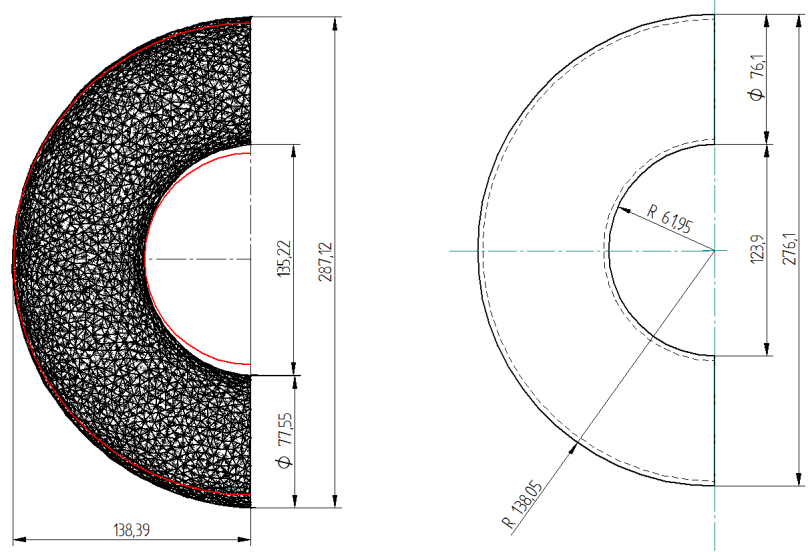

Fig. 6. Comparison of dimension.

\section{CONCLUSION AND RESUlts}

Following figure (Fig. 6) shows difference between ideal shapes of weld pipe elbow (Fig. 6. right) and simulation obtained shapes (Fig. 6 left). Most significant differences between ideal and simulated weld pipe elbow are, final 
diameter of pipe, where ideal dimension is $76,1 \mathrm{~mm}$ but dimension obtained from simulation is $77,55 \mathrm{~mm}$ (nominal difference is $1,45 \mathrm{~mm}$, thus $1,9 \%$ ). Overall prescribed width of ideal product is $276,1 \mathrm{~mm}$ but simulated dimension is $287,12 \mathrm{~mm}$ what is $11,02 \mathrm{~mm}$ difference compared to ideal value $(2,761 \%)$. Inner pitch of weld pipe elbow is according to documentation $123,9 \mathrm{~mm}$ but simulated dimension is 135,22 , difference is $11,32 \mathrm{~mm}(9,1 \%)$. Overall shape of simulated product is opened in comparison with ideal shape, what is represented by red lines in figure below (Fig. 6).

Subsequently will be performed experimental verification of obtained data by manufacturing of test samples using unimproved tool. Preliminary results shows that current shape and dimensions of tool do not ensure correct parameters of final product (weld pipe elbow). Change of dimensions and shape of the tool appears necessary, especially on calibration section.

\section{ACKNOWLEDGEMENT}

This paper has been elaborated in the framework of the project of the project VEGA 1/0492/16 and in cooperation FVT TUKE based in PO and R\&D Centre s.r.o. under contract no.01/2014.

\section{REFERENCES}

[1] Ž. Podbrezová. Ocel’ové rúrové navarovacie oblúky. [Online]. Available: http://www.zelpo.sk/rurove_tvarovky

[2] J. Hašan, "Rozmery oblúkov a úpichov - VÁhy úpichov," Železiarne Podbrezová a.s., Podbrezová, 2009.

[3] P. H. Hsu, S. Huang, C. C. Chiang, L. Tsai, S. H. Wang, and N. S. Liou, "Dynamic friction properties of stainless steels," in Proc. Conference Proceedings of the Society for Experimental Mechanics Series, pp. 149-154, vol. 85, 2016

[4] R. Durcikand L. Parilak, "Simulation of push-bench process in manufacturing of seamless tubes," in Proc. 21st International Conference on Metallurgyand Materials, 2012, pp. 423-427.

[5] F. Zhang, Y. Zhang, L. Zhang, and X. Hou, "The interplay between the measured dimension and temperature of hot large forgings," International Journal of Advanced Manufacturing Technology, vol. 81 no. 9, pp. 1619-1630, 2015.

[6] A. A. Rogovoy and N. K. Salikhova, "Finite-element modeling of plastic working of steel billets," 2016.

[7] R. Durčík and L. Parilák, "Numerical simulation of billet calibration and piercing in a push-bench seamless tube," in Proc. 23 International Conference on Metallurgy and Materials METAL, 2014,

[8] M. Mičko, J. Duplák, J. Zajac, M. Hatala, B. Kaczmarska, F. Botko et al., "Study of welding parameters effect on the weld quality for structural steel S235 J0," Key Engineering Materials, vol. 669, pp. 79-86, 2016.

[9] Z. Hutyrová, W. Makiela, P. Michalik, D. Mital', S. Radchenko, J. Duplák et al., "Creation of mathematical prescription of residual stress depending on various cutting conditions," Key Engineering Materials, vol. 669, pp. 126-133, 2016.

[10] D. Mital', P. Michalik, J. Duplák, S. Radchenko, J. Živčák, B. Kaczmarska et al., "Method for measurement of residual stresses using eddy currents," Key Engineering Materials, vol. 669, pp. 409-416, 2016.

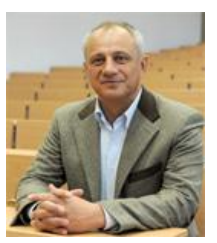

Jozef Zajac was born in Spišská Nová Ves, Slovakia, in 1960. He received the B.Eng and MSc. degrees (in 1989) in branch of mechanical engineering technology from Košice Technical College on Faculty of Mechanical Engineering and the Ph.D. degree in branch of manufacturing engineering technology in the Technical University of Košice on Faculty of Mechanical Engineering, in 1994. In years $1995-$ 1996 he was delegated the head of the Department of Manufacturing Technologies on Faculty of Manufacturing Technologies, TUKE, with a seat in Prešov and in 1996 to 1998 was business manager for CIMCOOL
EUROPE, B.V. He is currently a professor in the Technical University of Košice, Faculty of Manufacturing Technologies with a seat in Prešov. From 2003 to 2012 he was the head of the Department of Manufacturing Technologies, Faculty of Manufacturing Technologies with a seat in Prešov, TUKE. Since 2013, he has been the dean of the Faculty of Manufacturing Technologies, Tuke. He has published more than 200 scientific papers and books in domestic and international journals in the field of manufacturing technologies.

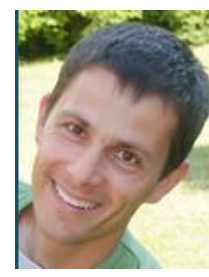

Pavol Beraxa was born in, Slovakia, in 1979. He received the B.Eng and MSc. degrees (in 2003) in branch of machine production management in the Technical University of Košice on Faculty of mechanical engineering. In 2014 he received the $\mathrm{Ph}$.D. degree in the Technical University of Košice on Faculty of manufacturing technologies in branch of manufacturing technologies. Since 2008, he has been employed in ŽP VVC, s. r. o as a head of Material Engineering Department.

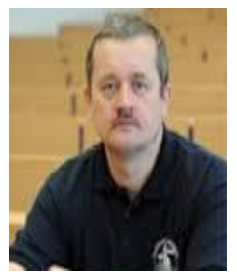

Peter Michalik was born in, Slovakia, in 1961. He received the B.Eng and MSc. degrees (in 1985) in branch of instrumentation, regulation and handling equipment in the Technical University of Košice on Faculty of Mechanical Engineering. From 1985 to 1993 he was employed as an engineer and designer of automated hanging tracks. From 1993 to 2009 he was employed as a teacher of technical subjects (programming CNC machines) on secondary school in Prešov. In 2009 he received the Ph.D. degree in the Technical University of Košice on Faculty of Mining in branch of Mining mechanization, transport and deepwater drilling. Since 2014, he has been the Associate professor on the Faculty of Manufacturing Technologies with a seat in Prešov, TUKE.

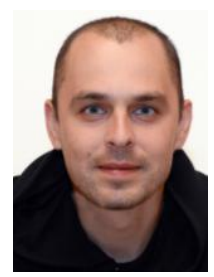

František Botko was born in Prešov, Slovakia, in 1982. He received the B.Eng and MSc. degrees (in 2006) in branch of mechanical engineering technology in the Technical University of Košice on Faculty of mechanical engineering. From 2006 to 2008 he was CNC programmer in Krizik GBI Prešov. From 2008 to 2014 he was process enginee technologist in Krizik GBI Prešov. At years 2013 to 2014 he was at employ position as head of Production Technology department in Krizik GBI Prešov business. Since 2014, he has been a PhD student in the Technical University of Košice on Faculty of Manufacturing technologies with a seat in Prešov. His professional specializations are progressive manufacturing technologies, non-destructive testing and manufacturing processes.

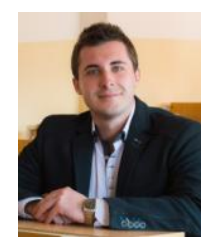

Martin Pollák was born in Bardejov, Slovakia, in 1989. He received the B.Eng and MSc. degrees (in 2014) in branch of computer aided of manufacturing technology in the Technical University of Košice on Faculty of Manufacturing Technologies. Since 2014 he has been a PhD student in the Technical University of Košice on Faculty of manufacturing technologies with a seat in Prešov. His research interests cover the computer aided design and analysis. His interests also include the area of application the database and expert systems in manufacturing technologies 